\title{
Original
}

\section{Regulation of Estrogen Activity in Human Endometrium : Effect of Cytokines on the Expression of Steroid Sulfatase and Sulfokinase mRNA in Human Endometrial Stromal Cells}

\author{
Yoshiaki Furusawa, Ryu Matsuoka, Atsushi Yanaihara, \\ Yoshiro TOMa, Taro Morimoto, Tomoko Yuasa, \\ Ryuzo Tahara, Hiroshi SaIto and Takashi OKaI
}

\begin{abstract}
Steroid sulfatase (STS) and sulfokinase (SK) are antagonistic regulators of local estrogen activity. STS and SK activities and the expression of some cytokines in human endometrium show menstrual cycle-dependent changes. However, the role of cytokines in the regulation of both enzymatic activities is unclear. In this study, we investigated the effects of cytokines on STS and SK activities by measuring their mRNA expression in human endometrial cells. Human endometrium was obtained from endocrinologically healthy women during gynecological surgery for either a benign disease or CIS. Endometrial stromal cells were isolated and cultured in the presence or absence of cytokines, IL-1 $\beta$ or IL-8. Total RNA was extracted and STS and SK mRNA expressions were measured using real-time PCR (LightCycler). Both IL-1 $\beta$ and IL-8 significantly reduced STS mRNA expression, whilst inducing SK mRNA expression. When an IL-1 receptor antagonist or CXCR-1 antibody was added simultaneously, the effect of IL-1 $\beta$ or IL-8 was neutralized. These results suggest that IL-1 $\beta$ and IL-8, which are more prevalent in the late secretory phase endometrium, regulate STS and SK mRNA expression and decrease the local estrogen effects in human endometrium.
\end{abstract}

Key words : steroid sulfatase, steroid sulfokinase, cytokines, real-time PCR, human endometrium

\section{Introduction}

Several steroid converting enzymes expressed in human endometrium show cyclic changes in their activities during the menstrual period and can also regulate the local estrogen effects $^{1-3)}$. The sulfation pathway comprising steroid sulfatase (STS) and sulfokinase (SK) is thought to be important in sex steroid metabolism. The pathway can be reversible in that SK catalyzes the sulfation reaction and STS catalyzes the hydrolysis of sulfate esters formed by the action of $\mathrm{SK}^{4)}$. Steroid sulfates do not interact with the appropriate hormone receptors; additionally the presence of the charged sulfate moiety increases the aqueous solubility and excretion of most steroids ${ }^{5)}$. Steroid sulfates, such as

Department of Obstetrics and Gynecology, Showa University School of Medicine, 1-5-8 Hatanadai, Shinagawa-ku, Tokyo 142-8666, Japan. 
dehydroepiandrosterone sulfate and estrone sulfate, exist in much higher concentrations in plasma and have lower biological activities than their unconjugated counterparts. Thus, the peripheral conversion of estrogens by STS and SK in human endometrium might regulate the estrogen action at the level of the tissue ${ }^{6,7)}$. Therefore, the regulatory mechanisms controlling STS and SK activities in human endometrium are important to clarify.

Inflammatory cytokines secreted in the human endometrium also show cyclic changes. The mRNA expressions of these cytokines are low during the proliferative and early secretory phase, increase from the mid-secretory phase, peaking in the late secretory phase $^{8,9)}$. Populations of inflammatory cells in the human endometrium fluctuate during the menstrual cycle, with increases seen during the secretory phase. Most of the cytokines are derived from these inflammatory cells, which are regarded as important for normal endometrial function through cell to cell interaction and cytokine secretion ${ }^{10,11)}$. We previously reported that IL-1 $\beta$ in human endometrium might decrease the local concentration of estradiol by controlling STS activity ${ }^{12)}$. We now speculate further that cytokines might regulate local estrogen actions in human endometrium. Here, we investigated the effects of IL-1 $\beta$ and IL-8 on STS and SK activity in cultured human endometrial cells by real-time PCR.

\section{Materials and Methods}

\section{Materials}

Fetal bovine serum (FBS) and DMEM F-12 HAM tissue culture medium were purchased from Gibco (Grand Island, NY). Recombinant human IL-1 $\beta$ was purchased from R\&D Systems Inc. (Minneapolis, USA). Recombinant anti-human IL-1 receptor antagonist (IL-1 ra) was purchased from IBL (Fujioka, Japan). Recombinant human IL-8 and monoclonal anti-human CXCR-1 antibody were purchased from Genzyme/Techne (Cambridge, U.S.A.). All other chemicals were reagent grade and obtained commercially.

\section{Tissue samples}

Human endometrium in mid-late proliferative phase was obtained from 4 patients (36-42 years old) undergoing hysterectomy for benign disease or CIS. All patients were endocrinologically healthy and had regular menstruation cycles. Informed consent was obtained from all patients. The menstrual cycle was determined both by the date of the last menstrual period and the serum concentrations of estradiol and progesterone.

\section{Endometrial stromal cell culture}

Human endometrial tissue samples were removed from the uterus immediately after the operation and were washed with icecold Hanks' balanced sodium solution (HBSS, Gibco BRL, Grand Island, NY, USA), then minced into small pieces. Stromal cells were isolated from the epithelial cells by the method described previously ${ }^{13,14)}$. Briefly, the tissue fragments were digested with HBSS containing $0.25 \%$ collagenase in a humidified $5 \% \mathrm{CO}_{2}$ atmosphere at $37^{\circ} \mathrm{C}$ for $90 \mathrm{~min}$ with agitation. After digestion, the samples were separated into stromal and epithelial cells by filtration. Cell pellets were washed with DMEM F-12 HAM culture medium containing $10 \%$ FBS, $100 \mathrm{IU}$ penicillin/ml and $100 \mu \mathrm{g}$ streptomycin/ $\mathrm{ml}$. The stromal cells were then plated onto $100 \mathrm{~mm}$ tissue culture dishes and the medium was changed every 48 hours. After the cells became pre-confluent, cells were subcultured 
into 12-well dishes in DMEM F-12 HAM without FBS for another 24 hours. IL-1 $\beta$ ( 10 $\mathrm{ng} / \mathrm{ml})$ or IL-8 $(10 \mathrm{ng} / \mathrm{ml})$ was then added in the medium and incubated for either 24 hours (IL-1 $\beta$ ) or 48 hours (IL-8). Interleukin-1 ra $(100 \mathrm{ng} / \mathrm{ml})$ and anti-human CXCR-1 antibody $(0.2 \mu \mathrm{g} / \mathrm{ml})$ were added concurrently with the IL-1 $\beta$ or IL-8. The incubations were terminated by removal of the medium and the cells were stored frozen at $-80^{\circ} \mathrm{C}$ until the RNA extraction.

\section{Measurement of $\mathrm{mRNA}$ expression by real-time PCR}

Total RNA was extracted from cells by the standard acid guanidinium isothiocyanatephenol-chloroform extraction procedure using Trizol reagent (Life Technologies, Inc. Grand Island, NY ${ }^{15)}$. Following isolation, the concentration and purity of the RNA preparations were measured by optical density at 260 and $280 \mathrm{~nm}$. $100 \mathrm{ng}$ of total RNA was reverse transcribed for $30 \mathrm{~min}$ at $55^{\circ} \mathrm{C}$ and for $5 \mathrm{~min}$ at $99^{\circ} \mathrm{C}$ using $1.25 \mathrm{pmol}$ oligo dT primers (Takara Shuzo, Tokyo, Japan). Real-time PCR was carried out with the LightCycler Instrument (Roche Molecular Biochemicals, Mannheim, Germany) using the DNA binding dye SYBR Green I. PCR reactions were set up using $2 \mu 1$ PCR master mix (LightCyclerDNA Master SYBR Green I ${ }^{16,17)}$, supplemented with $3.0 \mathrm{mM} \mathrm{MgCl}_{2}$ and self designed primers and $2 \mu \mathrm{l}$ of either external standards or a cDNA equivalent to 10ng total RNA to give a final reaction volume of $20 \mu \mathrm{l}$. Primers to detect STS spanned exon to exon of STS and amplified a product of 376 bps with the following sequences: sense 5'AACTCACTCAGCACCTGGCA-3' and antisense 5'-GGGAGGAAGACCAGCCTCTT-3' (nucleotides $394-769)^{12}$. At the same time, primers to detect SK amplified a product of 399 bp with the following sequences: sense 5'-CATGAAGGAGAACCCCAAAA-3' and antisense 5'-CCACTGTGCCTGACTCAAAAAATACATCAAACGCCGCGAC-3' (nucleotides 649-1047). The PCR settings were as follows: $95^{\circ} \mathrm{C}$ for $15 \mathrm{sec}, 55^{\circ} \mathrm{C}$ for $5 \mathrm{sec}, 72^{\circ} \mathrm{C}$ for $\mathrm{bp} / 25 \mathrm{sec}$. The PCR cycle was repeated 45 times and then melting curve analysis was carried out (increasing temperature from $65^{\circ} \mathrm{C}$ to $95^{\circ} \mathrm{C}$ ) to check for primer dimer. To calibrate the amount of mRNA, the expression of G3PDH mRNA was measured.

\section{Preparation of quantitative standards}

PCR products for cloning were prepared using cDNA extracted from the placental tissue by the Takara RNA PCR kit (Takara Shuzo, Tokyo, Japan). The product contained a single band of the expected size ( 379 bps for STS, 399 bps for SK) by agarose gel electrophoresis and ethidium bromide staining. The PCR product was contaminated plasmid DNA and cloned using the TOPO TA cloning kit (Invitrogen, Leek, Netherlands). Plasmids were purified from E. coli grown overnight in Luria-Bertani medium using a mini-prep kit (Sigma Chemical Co, St. Louis, U.S.A). Analysis of the sequence of standards was carried out using ABI PRISMTM 310 Genetic Analyzer (PE Applied Biosystems Tokyo). Plasmid preparations were quantified spectrophotometrically and standards were prepared by serial dilution.

\section{Statistical analysis}

Reverse transcription/real-time PCRs were run in duplicate and the results are given in $\log$ units of mean \pm standard deviation of STS or SK mRNA/G3PDH mRNA ratio from each group. The results were compared by one-way analysis of variance (ANOVA) with 


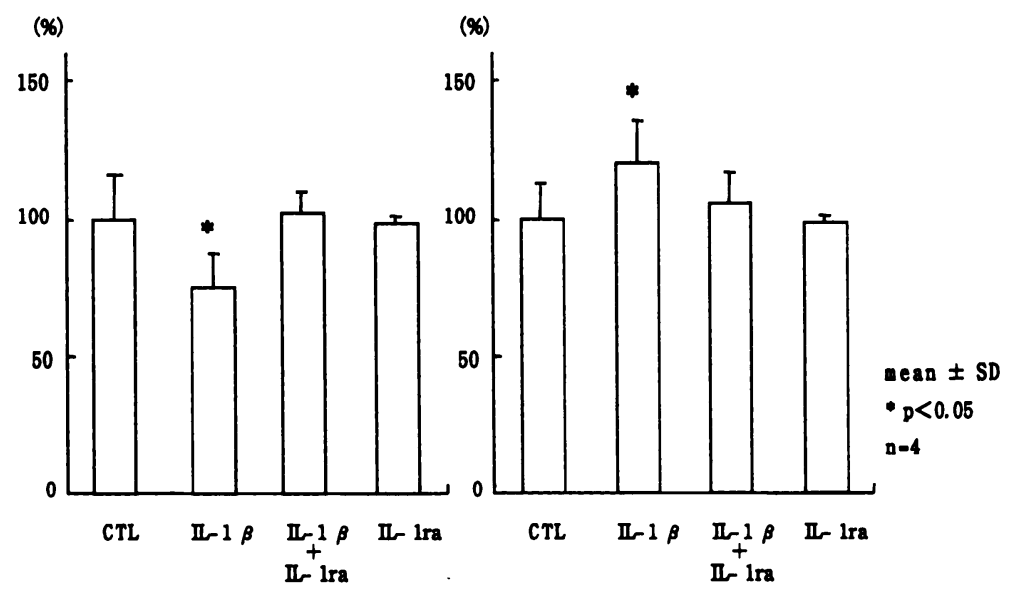

Fig. 1. Effect of IL-1 $\beta$ on STS and SK mRNA expression

IL-1 $\beta(10 \mathrm{ng} / \mathrm{ml})$ and IL-1 receptor antagonist (IL-1 ra) $100 \mathrm{ng} / \mathrm{ml}$ were added and cells were incubated for $24 \mathrm{~h}$. The method of real-time PCR was described in the text. Results are expressed as a percentage of the control level, which was set to $100 \%$. Values represent mean $\pm \mathrm{SD}$ of 4 experiments. ${ }^{*} \mathrm{p}<0.05$

multiple comparison tests using Stat View-J 4.5 (Abacus Concepts, Inc. Tokyo). Statistical significance was taken as $P<0.05$.

\section{Results}

\section{Effect of IL-1 $\beta$ on STS and SK mRNA expression}

We investigated the effect of IL-1 $\beta$ on STS and SK mRNA expression by real-time PCR (Fig. 1). Administration of IL-1 $\beta$ for 24 hours significantly $(P<0.05)$ reduced the expression of STS mRNA to $74.2 \pm 13.4 \%$ of the control (no cytokine added). When IL-1 ra was added together with the IL-1 $\beta$, the STS mRNA expression decrease was reversed. In contrast, administration of IL-1 $\beta$ significantly $(P<0.05)$ induced the expression of SK mRNA to $120.7 \pm 14.7 \%$ of the control. As with the STS effect, the addition of IL-1ra together with the IL-1 $\beta$ abrogated the induction of the SK mRNA expression.

\section{Effect of IL-8 on STS and SK $m R N A$ expression}

We also investigated the effect of IL-8 on STS and SK mRNA expression by real-time PCR (Fig. 2). Administration of IL-8 for 48 hours significantly $(P<0.05)$ reduced the expression of STS mRNA to $74.6 \pm 18.2 \%$ of the control. When anti-human CXCR-1 antibody was added together with the IL-8, the expression was neutralized. As with the IL-1 $\beta$ effect, administration of IL-8 significantly $(P<0.05)$ induced the expression of SK mRNA to $124.0 \pm 19.3 \%$ of the control, and this effect was reversed by the concurrent addition of anti-human CXCR-1 antibody. 

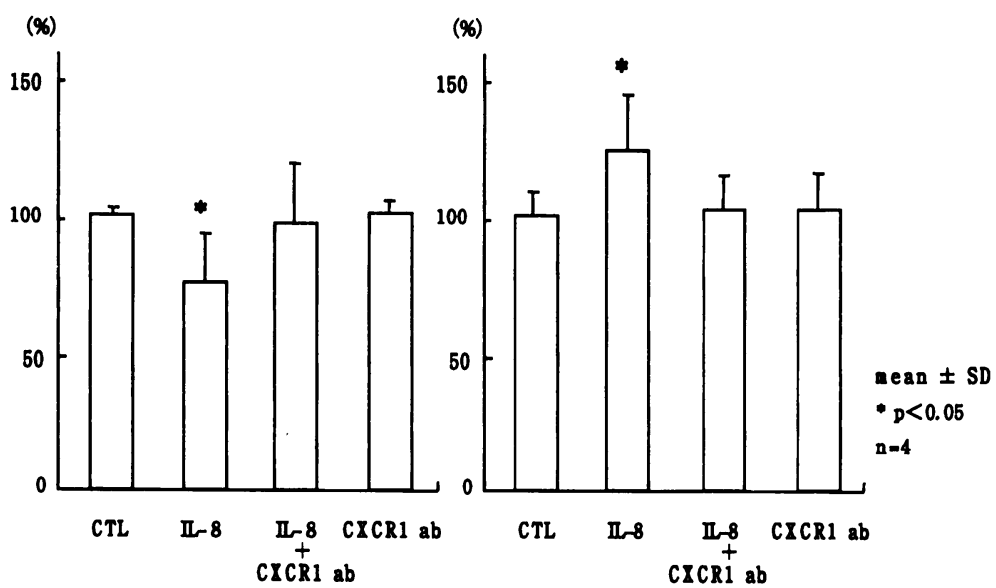

Fig. 2. Effect of IL-8 on STS and SK mRNA expression

IL-8 $(10 \mathrm{ng} / \mathrm{ml})$ and CXCR1 antibody $0.2 \mu \mathrm{g} / \mathrm{ml}$ were added and cells were incubated for $48 \mathrm{~h}$. The method of real-time PCR was described in the text. Results are expressed as a percentage of the control level, which was set to $100 \%$. Values represent mean \pm SD of 4 experiments. ${ }^{*} \mathrm{p}<0.05$

\section{Discussion}

Several cytokines are expressed in human endometrium and their concentrations fluctuate during the menstrual cycle and pregnancy. These cytokines show a discrete localization in human endometrium ${ }^{8,9,18-20)}$. The mRNA expression of tumour necrosis factor (TNF), IL$1 \beta$, IL-6, IL-8, leukaemia inhibitory factor (LIF), transforming growth factor $\beta 1$ (TGF$\beta 1$ ), macrophage colony stimulating factor (MCSF) and vascular endothelial growth factor (VEGF) was low during the proliferative and early secretory phases of the menstrual cycle, increased from the mid-secretory phase to a peak in the late secretory phase ${ }^{21)}$. Diffuse cytoplasmic expression of IL-1 $\beta$ in endometrial epithelium during the proliferative phase contrasted markedly with its enhanced luminal expression during the secretory phase of the menstrual cycle ${ }^{22)}$. IL-8 mRNA expression is localized in perivascular cells of the late secretory phase endometrium and decidua, and this is up-regulated by the withdrawal of progesterone $^{19)}$. IL-8 can also induce a concentration-dependent increase in cell adhesion to the fibronectin matrix ${ }^{23)}$, and shows a cycle-dependent expression in human endometrium as well as during stimulated endometrium stromal cell growth ${ }^{24)}$. Progesterone and a synthetic progestin, medroxyprogesterone acetate (MPA) act to enhance the action of IL-1 $\beta$ to increase the level of IL-8 $\mathrm{mRNA}^{25)}$. Together, these reports implicate the menstrual cycle-dependent changes in the expression of these cytokines in human endometrium to the human endometrial functions.

We previously reported that administration of IL-1 $\beta$ decreases STS mRNA expression as well as STS activity in human endometrium stromal cell cultures. From this, we postulated that IL-1 $\beta$ might depress the local estrogen activity in human endometrium by controlling STS activity and that STS mRNA expression might be a rate-limiting step for the function of STS $^{12)}$. STS and SK in human endometrium act to counter-regulate the tissue 
concentration of estrogens. Like SK, estrogen sulfotransferase is expressed in the human endometrium in a cyclical manner ${ }^{26)}$. In addition, its expression appears to be induced by progesterone $^{6,27)}$, indicating that progesterone might regulate the estrogenic stimulation of the endometrium during the menstrual cycle. The expression of immunoreactive estrogen sulfotransferase and its mRNA in the Ishikawa cells were increased by progesterone. However, estrogen sulfotransferase activity was not induced by treatment of Ishikawa cells with varying concentrations of estradiol, testosterone or cortisol. The induction of estrogen sulfotransferase activity by progesterone was however inhibited by RU-486, indicating that progesterone is acting via the progesterone receptor ${ }^{27)}$.

We have measured STS and SK activities in tissue homogenates of human endometrium using radiolabeled substrates, and found STS activity to be about 5 times higher than SK activity $^{2}$. From previous reports of the Michaelis-Menten constants $(\mathrm{Km})$ for STS and SK in various tissues, SK has a higher affinity for the substrates than STS ${ }^{28-30)}$. These studies used a cell free homogenate or enzyme rich fraction as the enzyme source. Thus, it is difficult to interpret the classical enzyme reaction of STS and SK in cell culture systems.

Real-time PCR is more sensitive with higher accuracy and reproducibility than conventional, competitive RT-PCR methods. Therefore, in the present study, we simultaneously measured STS and SK mRNA expressions in human endometrium by real-time PCR. We found that both IL-1 $\beta$ and IL-8 increased the expression of SK mRNA in cultured human endometrium, whilst decreasing STS mRNA expression. In addition, these effects were shown to be receptor mediated. Therefore, these cytokines appear to act as down-regulators of estrogenic activity in human endometrium due to their up- and down-regulation of SK and STS, respectively. Although the mRNA expression measured in the present study can not be used to interpret the enzymatic activities of STS and SK directly, this is the first report on the effect of cytokines on STS and SK mRNA expression in human endometrium. It is well established that progesterone induces the differentiation of human endometrium, therefore further study is necessary to determine the effect of sex steroids on the induction mechanisms of STS and SK mRNA by IL-1 $\beta$ and IL-8.

In conclusion, we propose that IL- $\beta$, IL-8 and some other cytokines may act as regulators of endometrial cell growth, menstruation, implantation and the maintenance of early pregnancy. These cytokines have an important role in endometrial function via their effect on cell to cell interactions. Therefore, cytokines might regulate the activities of steroid converting enzymes in controlling endometrial function and maintaining an appropriate condition of the endometrium.

\section{References}

1) Prost $O$ and Adessi GL: Eștrone and dehydroepiandrosterone sulfatase activities in normal and pathological human endometrium biopsies. J Clin Endocrinol Metab 56 : 643-661 (1983)

2) Seki M, Hara Y, Sekiya M, Itagaki T, Hirato K, Yanaihara T and Nakayama T: Changes in steroid enzyme activity in the human endometrium during the menstural cycle. Acta Obst Gynaec Jpn 39 : 1571-1578 (1994)

3) Josie LF, Ricardo A and Charles NF: Identification and characterization of cytosolic sulfotransferases in normal human endometrium. Chem Biol Interact 109 : 329-339 (1999)

4) Coughtrie MW, Sharp S, Maxwell $\mathrm{K}$ and Innes NP: Biology and function of reversible sulfation pathway catalysed by human sulfotransferases and sulfatases. Chem Biol Interact 109:3-27 (1998)

5) Kotov A, Falany JL, Wang $J$ and Falany $\mathrm{CN}$ : Regulation of estrogen activity by sulfation in human Ishikawa endometrial adenocarcinoma cells. J Steroid Biochem Molec Biol 68 : 137-144 (1999) 
6) Clarke CL, Adams JB and Wren BG: Induction of estrogen sulfotransferase in the human endometrium by progesterone in organ culture. J Clin Endocrinol Metab 55:70-75 (1982)

7) Pack BA, Tovar R, Booth E and Brooks SC: The cyclic relationship of estrogen sulfurylation to the nuclear receptor level in human endometrial curettings. J Clin Endocrinol Metab 48 : 420-424 (1979)

8) Tabibzadeh $\mathrm{S}$ and Sun $\mathrm{XZ}$ : Cytokine expression in human endometrium throughout the menstrual cycle. Hum Reprod 7 : 1214-1221 (1992)

9) Tabibzadeh S: Cytokines regulation of human endometrial function. Ann NY Acad Sci 622:89-98 (1991)

10) Jones RL, Kelly RW and Critchley HO : Chemokine and cyclooxygenase-2 expression in human endometrium coincides with leukocyte accumulation. Hum Reprod 12 : 1300-1306 (1997)

11) Vince GS and Johnson PM : Leucocyte populations and cytokine regulation in human uteroplacental tissues. Biochem Soc Trans 28 : 191-195 (2000)

12) Matsuoka R, Yanaihara A, Saito H, Furusawa Y, Toma Y, Simizu Y, Yanaihara T and Okai T: Regulation of estrogen activity in human endometrium: Effect of IL-1 $\beta$ on steroid sulfatase activity in human endometrial stromal cells. Steroids $67: 655-659$ (2002)

13) Satyaswaroop PG, Bressler RS, De La Pena MM and Gurpide E : Isolation and culture of human endometrial glands. J Clin Endocrinol Metab 48 : 639-640 (1979)

14) Vigano P, Di Blasio AM, Antonio GD and Vignali M: Culture of human endometrial cells: a new simple technique to completely separate epithelial glands. Acta Obstet Gynecol Scand 72:87-92 (1993)

15) Chomczynski $\mathbf{P}$ and Sacchi $\mathbf{N}$ : Single-step method of RNA isolation by acid guanidinium thiocyanate-phenolchloroform extraction. Anal Biochem 162:156-159 (1987)

16) Komurian-Pradel F, Paranhos-Baccala G, Sodoyer M, Chevallier P, Mandrand B, Lotteau V and Andre P : Quantitation of HCV RNA using real-time PCR and fluorimetry. J Virol Methods 95:111-119 (2001)

17) Brechtbuehl K, Whalley SA, Dusheiko GM and Saunders NA : A rapid real-time quantitative polymerase chain reaction for hepatitis B virus. J Virol Methods 93 : 105-113 (2001)

18) Arici A, Seli E, Senturk LM, Gutierrez LS, Oral E and Taylor HS : Interleukin-8 in the human endometrium. J Clin Endocrinol Metab 5 : 1783-1787 (1998)

19) Bergqvist A, Bruse C, Carlberg and Carlstrom $\mathrm{K}$ : Interleukin-1 $\beta$, interleukin-6, and tumor necrosis factor- $\alpha$ in endometriotic tissue and in endometrium. Fertil Steril $75: 489-495$ (2001)

20) Simon C, Piquette GN, Frances A and Polan ML: Localization of interleukin-1 type I receptor and interleukin-1 beta in human endometrium throughout the menstrual cycle. J Clin Endocrinol Metab 77 :549555 (1993)

21) Wolff M, Thaler CJ, Strowitzki T, Broome J, Stolz W and Tabibzadeh S : Regulated expression of cytokines in human endometrium throughout the menstrual cycle: dysregulation in habitual abortion. Mol Hum Reprod 6: 627-634 (2001)

22) Tabibzadeh $\mathrm{S}$ and Sun $\mathrm{XZ}$ : Cytokine expression in human endometrium throughout the menstrual cycle. Hum Reprod 7 : 1214-1221 (1992)

23) Juan A, Velasco $G$ and Arici A : Interleukin-8 stimulates the adhesion of endometrial stromal cells to fibronectin. Fertil Sterlil 72:336-340 (1999)

24) Juan A, Velasco G and Arici A : Chemokines and human reproduction. Fertil Sterlil 71:983-993 (1999)

25) Kelly RW, Illingworth P, Baldie G, Leask R, Brouwer S and Calder AA : Progesterone control of interleukin-8 production in endometrium and chorio-decidual cells underlines the role of the neutrophil in menstruation and parturition. Hum Reprod 9 : 253-258 (1994)

26) Buirchell BJ and Hähnel A : Metabolism of estradiol-17 $\beta$ in human endometrium during the menstrual cycle. J Steroid Biochem 6 : 1489-1494 (1975)

27) Falany JL and Falany $\mathrm{CN}$ : Regulation of estrogen sulfotransferase in human endometrial adenocarcinoma cells by progesterone. Endocrinology $137: 1395-1401$ (1996)

28) Klein H, Molwitz $T$ and Bartsch W: Steroid sulfate sulfatase in human benign prostatic hyperplasia: characterization and quantification of the enzyme in epithelium and stroma. J Steroid Biochem 33:195-200 (1989)

29) Gibb W and Lavoie JC: Kinetic studies on the formation of estrogens from dehydroepiandrosterone sulfate by human placental microsomes. Endocrinology 114 : 2323-2329 (1984)

30) Tseng L, Lee LY and Mazella J : Estrogen sulfotransferase in human placenta. J Steroid Biochem 22:611-615 (1985) 